\title{
COPING STRATEGY OF WOMEN ANXIETY IN REGENCY PERIOD AS REFLECTED IN "PRIDE AND PREJUDICE" MOVIE
}

\author{
Nensia \\ Sekolah Tinggi Ilmu Pariwisata Tamalatea Makassar \\ nensia@stipartamalatea.ac.id
}

\begin{abstract}
This research aims to describe coping strategy of women anxiety in Regency period as it is reflected in the movie of Pride and Prejudice. The method used in this study was a descriptive qualitative. The primary data used were the dialogues in the movie "Pride and Prejudice". The result of this study indicated that women in Regency period depicted in this literary work employed interesting coping strategies in their life where they deeply concerned about their future significantly money, higher social status, and marriage caused by anxiety.
\end{abstract}

Keywords: Coping Strategy, Anxiety, Regency Period, Women.

\section{INTRODUCTION}

Literature of England nineteen century employed a well-arranged life for the women in order to avoid a hard life because marriage, social status and money were a social institution. Thus of course evoke great anxiety toward people at that time. Moreover, women should only stay at home then would be considered as good quality women. Developing skills was also matters due to people would love to talk and gossip about what you are good at. Of course those skills had to be skills that being employed at home such as sewing, singing, playing the piano, and other conservative hobbies to attract a suitable husband.

"Women's contribution was at a low rate, and women were not allowed to work outside of home" (Strossmayera, 2015). Thus, women were considered as weak and independent because they had to depend on their husband economically. Therefore, looking for a rich or nobleman and keeping family dignity were becoming a great anxiety for people especially women.

According to Moss (2014), Anxiety is psychological response of a human being towards harm and danger. It roles as an alarm causing human worry about something and putting self-defense or coping mechanism.

\section{British, Jurnal Bahasa dan Sastra Inggris}


Coping mechanism is strategy used by an individual as a response in order to avoid anxiety, danger, or even unwanted consequences from not being able to cope with the anxiety. Each individual might employ different strategy. It depends on behavior, way of thinking, and social judgment as well.

Gender might also be the factor of different ways of coping strategy. For example men did not apply the same rule as women in Regency period. As to Hughes (1998), both of men and women loved assemblies in this period which used especially for young women as a perfect opportunity for matchmaking and showing the best of them. This balls venue was also represented in Pride and Prejudice where we can see the effort of Mrs. Bennet and how anxious she was to arrange the meeting of her daughter Jane and Mr. Bingley.

Thus, no wonder many writers decided to explore women issues in this period. As above description which reflected in one of Jane Austen's work namely Pride and Prejudice. Hence, the writer would like to describe the coping strategies resulted by women anxiety in this period as reflected in this literary work. It also can be a further reference for reader to visualize the social history of Regency period.

\section{RESEARCH METHOD}

This study employed descriptive qualitative method. In this regards, the steps taken were listing the data, analyzing the data, and presenting the result of the analysis.

The primary data was the movie dialogue of Pride and Prejudice direceted by Joe Wright based on Jane Austen's novel. While the secondary data sourced from journal, book, and internet sources as well.

The writer used note-taking method in order to list the data. First of all through watching the primary data, understanding the secondary data, and taking note of those data. Then figuring out the connection with related dialogues in order to find out the representation of secondary data in the movie. 


\section{RESEARCH FINDING AND DISCUSSION}

Sigmund Freud was the first person who introduced anxiety theory in 1890 . While Coping mechanism is a sign that an individual is having anxiety problem. In this research, the writer would present the analysis per woman character.

\section{Mrs. Bennet}

Mr. Bennet : "How can that possibly affect them?"

Mrs. Bennet : "How can you be so tiresome. He must marry one of them. You must go and visit him at once.

For we may not visit if you do not, as you well know.

Mr. Bennet : "There's no need, I already have.

Mrs. Bennet :"You have? When? Oh, Mr. Bennet how can you tease me so. Have you no compassion for my poor nerves." (Time $00: 03: 27 \rightarrow 00: 04: 13)$

Above dialogues show that Mrs. Bennet quite forcing effort to Mr. Bennet so that their daughters could have an opportunity to meet Mr. Bingley who is known as a noble and rich single man. In order to achieve her desire to marry them with fine man. She did realize that as women in this period and her status also, she cannot manage such occasion, therefore the coping strategy she chose is to force Mr.Bennet. Even, at the ball she did it again as shown in below dialogue.

Mrs. Bennet : "Mr.Bennet you must introduce him to the girls immediately. (Time 00:07:21 $\rightarrow 00: 07: 24$ ).

In this scene, Mr. Bennet looks uncomfortable. Then Mrs.Bennet directly gathered her daughters to Mr. Bingley which this looks slight impolite to just straightaway to nobleman. Her anxiety about having her daughter with a nobleman causing her took an act out of embarrassed. Luckily her daughters got to blathered with Mr. Bingley and Mr. Darcy who is richer than Mr. Bingley.

Even, Jane danced with Mr. Bingley. But Mrs. Bennet won't stop bother until she gets what she wants so she did thing as follow.

Mr. Bingley : "I enjoyed that so much Miss Lucas" after dancing.

(Mrs. Bennet come closer seeing the man dance with another woman.)

Mrs. Bennet : "How well you dance Mr. Bingley. My daughter Jane is a splendid dancer, is she not?

Mr. Darcy : "She is indeed"

.... "You friend Ms.Lucas is the most amusing young woman."

Elizabeth : "Oh yes, I adore her" cheerfully.

Mrs. Bennet : "It's a pity she's not more handsome."

Elizabeth : "Mama."

\section{British, Jurnal Bahasa dan Sastra Inggris}


Mrs. Bennet : "Oh, but Lizzie would never admit that's she's plain. Of course it's my Jane who is considered the beauty of the county.

Jane $\quad$ : "Mama please". Embarrassedly (Time 00:11:50 $\rightarrow 00: 12: 37$ )

Above situation shows how persistent Mrs. Bennet is in getting Mr. Darcy's intention only to her daughter. Here, promoting Jane frankly is the coping strategy she chose. Unfortunately, it is just making Jane and Elizabeth anxious about other people's opinion about this embarrassing way. Therefore, they try to stop their mother talking. But Mrs. Bennet anxiety has control over her dignity as follow.

Mr. Bennet : "The way you carry on, you'd think our girls look forward to a grand inheritance."

Mrs. Bennet : "When you die, which may be very soon, they will be left without a roof over their head nor a penny to their name." (Time $00: 15: 04 \rightarrow 00: 15: 16$ )

This clearly means that she is anxious for her daughter future. Therefore, as any woman in Regency period would try the best to make a better life and she thought her coping strategy as at the ball would make a fortune. Even, later she did more than that when Jane got invitation from Mr. Darcy's sister, Caroline Bingley.

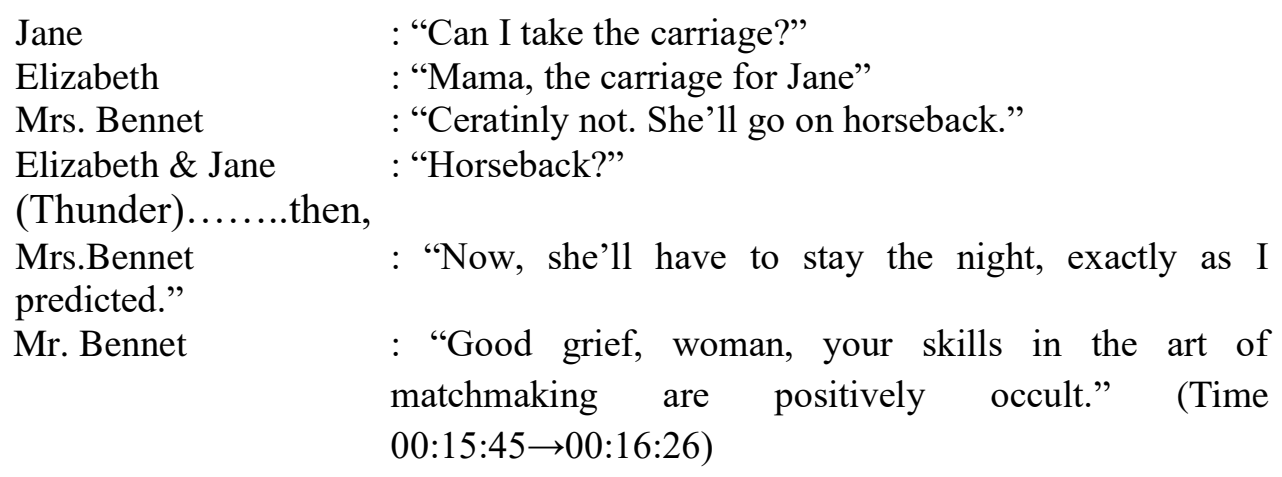

From above conversation, the coping strategy that Mrs. Bennet used is taking one level up than before. She predicted the way to make Jane stay longer in Mrs. Bingley's hall. Moreover, Jane got sick and will only allowed to return after recover. She did this also to Elizabeth. When Mr. Collins, the one to inherit Mr. Bennet property, came to marry Jane, she offered him Elizabeth.

Mrs. Bennet : "Oh certainly, Lizzie would be very happy indeed. Everyone, out. Mr. Collins would like a private audience with your sister. (Time 00:46:29 $\rightarrow 00: 46: 37$ ) 
On above scene, Mr. Collins is Mr. Bennet nephew which the rule and culture in this period for a family who does not have male as the descendant, then the inheritance will be fell to the nephew of the father. This is happened in Bennet family where all children born female. This became Mrs. Bennet persistent motive where she managed her daughters to be married to good rank man. In this scene, Mr. Collins actually asked for Jane but Mrs.Bennet was sure that Jane will marry Mr. Bingley therefore Mrs. Benner offer him to choose Elizabeth instead. Mrs. Bennet consideration is because Mr. Collins will be the one to inherit Mr.Bennet property as in below scene:

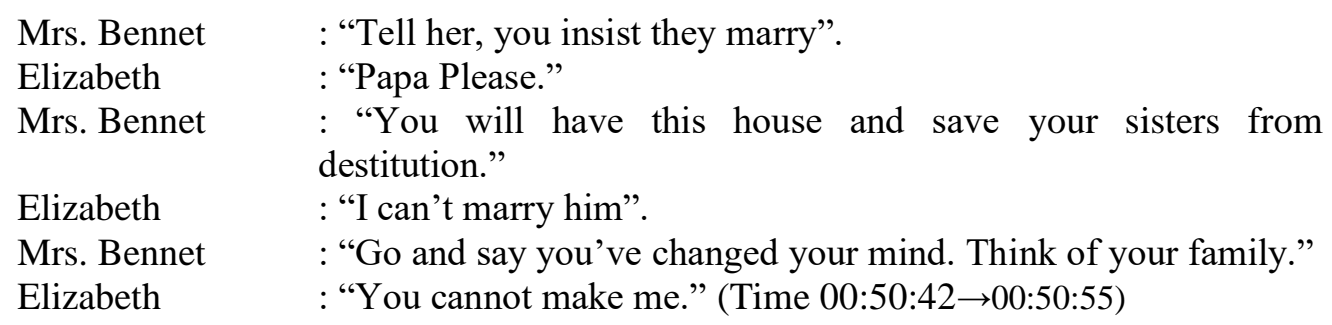

In this situation, Elizabeth refuse Mr. Collin's offer which made Mrs. Bennet angry and force her husband to ask Elizabeth to apologize and marry Mr. Collins. Clearly it states Mrs. Bennet reason in above conversation. She sacrifice Elizabeth in order to save her family. This is also happened in the reality of this period where women did not marry of love but to avoid miserable life.

Not only above points, but also to be a descent woman, the dignity of family's name should be kept. It is reflected in below scene:

Mrs. Bennet : "And now she is ruined. You are all now ruined. Who will take you now with a fallen sister? „Mr. Collins will turn us out before he is cold. ..How could she do such a thing to her poor mama." (Time $01: 32: 50 \rightarrow 01: 33: 33)$

This scene took place when Lidya Bennet ran away with Mr. Wickham (a tricky officer) shows that Mrs. Bennet is more anxious about the name of the family then where Lidya was. This shows that social reputation is all matter to be engaged. She is anxious that no one would take her daughters as wife after all she has done to try the best of her.

\section{Elizabeth Bennet}

Elizabeth : :Do you dance Mr. Darcy?

Mr. Darcy : "Not if I can help it." (Time 00:09:36 $\rightarrow$ 00:09:39)

\section{British, Jurnal Bahasa dan Sastra Inggris}


Then Elizabeth expression looks embarrassed for asking such question which can be inferred as an offer to dance but the answer make her speechless. They are both quite. Therefore, in order to get out of the awkward situation, she copes with it by leaving him with a bow down. This is not the only uncomfortable situation about Mr. Darcy, also when she and her friend, Ms. Lucas unintentionally heard him talking to Mr. Darcy as follow:
Mr.Bingley : "But her sister Elizabeth is agreeable"
Mr. Darcy : "Perfectly tolerable. Not handsome enough to temp me"
Ms. Lucas : :Count your blessings Lizzie, if he liked you, you'd have to talk to him."
Elizabeth : "Precisely. I wouldn't dance with him for all of the Derbyshire. Let alone the miserable half." They laughed. (Time 00:10:16 $\rightarrow 00: 10: 41$ )

After hearing these man's conversation, Elizabeth looks so disappointed and embarrassed because her friend also heard it. The good thing is the coping strategy she chose is making fun out of it.

We can see that Elizabeth is different with her mother. It is shown in below conversation:
Mrs. Bennet : "When she was 15 , a gentleman was so much in love with her. I was sure he would make her an offer. However he did write her some very pretty verses"
Elizabeth : "and that put paid to it" interrupted. "I wonder who discovered the power of poetry in driving away love."
Mr.Darcy : "I thought poetry was the food of love."
Elizabeth : : "Of a fine, stout love. ...." (Time 00:12:37 $\rightarrow 00: 12: 58$ )

This situation shows that Jane and Elizabeth did not feel comfortable with her mother's topic so the strategy that Elizabeth used to stop her is to interrupt her and talking about other thing that her mother would not get in to the talk. Then Mr. Darcy ask her.
Mr. Darcy
: "So what do you recommend to encourage affection?"
Elizabeth
: "Dancing. Even if one's partner is barely tolerable." (Time 00: $12: 58 \rightarrow 00: 13: 07)$.

Mr. Darcy paused. Elizabeth smile, bow down, then leave. It feels like Elizabeth had coped with her previous two embarrassments, the dancing offer and the tolerable looking that not handsome enough. She used a smart way that pause Mr. Darcy. 


\section{Lidya Bennet}

Lidya : "I can't breathe. I think one of my toes just came off." (Time $00: 05: 35 \rightarrow 00: 05: 41)$

She said this while dancing and smiling. It shows that she restrained the pain because she was worried that she would look ugly. So she cope it by smiling. For her, looking good is all matter to attract man. Another strategy as follow:

Kitty :"How will we meet them?"

Lidya : "Easy. You drop something. Then picked it up. And then you're introduced. (Time 00:19:12 $\rightarrow 00: 19: 17$ )

This scene set up in an officers long march. They have planned to do this since they found out that officers would stay in their country for months. In Regency period, officer is also considered as fine man to increase the social status. So this trick is Lidya's coping strategy in order to get acquainted with the officers. Even if it is in a shameless way as stated below:

\footnotetext{
Lidya :"Mr. Bingley, is it true you will hold a ball here?"

Mr. Bingley : :A ball?" Smiling but confused.

Lidy : "It would be an excellent way to meet new friends. You could invite the militia."

Kitty $\quad$ :" Oh, do hold a ball."

Mr. Bingley :"When your sister recover, you should name the day." (Time $00: 24: 19 \rightarrow 00: 24: 33)$.
}

As on the above situation, Lidya's strategy is shameful for setting a trap like this which all people at that time knew that Mr.Bingley never have such plan. The scene took place at Mr. Bingley's hall when Bennet family came to take Jane home. She must have known that Mr.Bingley is a good man and interested to her sister that he could not resist Lidya's true intention. Lidya was anxious that her previous strategy did not success so she set next strategy in order to meet the militia.

\section{Kitty Bennet}

Kitty : "I have to have your muslin! I'll lend you my green slippers. I'll do your mending for a week.

Lidya : "I'll retrim your bonnet"

Kitty : "Two weeks I'll do it for" (Time 00:04:32 $\rightarrow$ 00:04:42)

From above situation, the writer identified that Kitty's spontaneous idea to borrow Jane's good stuff shows that she has anxiety in looking good. This is the

\section{British, Jurnal Bahasa dan Sastra Inggris}


coping strategy that she used even she would barter it with several stuffs and raise the offer when Lidya gets involved.

\section{Ms. Lucas/Charlotte}

Charlotte :"I've come here to tell you the news. Mr. Collins and I are engaged."

Elizabeth :'Engaged? „, But he's ridiculous.

Charlotte :'Oh hush, Not off all us can afford to be romantic. I've been offered a comfortable home and protection. There's a lot to be thankful for. I'm 27 years old. I've no money and no prospects. I'm already a burden to my parents. And I'm frightened. So don't judge me Lizzie." (Time 00:54:52 $\rightarrow 00: 55: 44$ ).

As stated on above situation, it mirrored women culture on marriage. Money comes first. It does not matter if the man is not good looking as long the woman no need to be anxious for her future. Therefore, Love was not important in this period. Here, the writer sees that aged 27 is old enough for a woman who does not marry yet. Thus, Charlotte was so scared for becoming a burden to her family and society would look down on her. It also reflects the mindset of people in this period.

\section{Caroline Bingley}

Elizabeth :'I don't understand what would take him from Netherfield. Why does he not know when he'll return."

Jane $\quad$ :'Read it, I don't mind."

Elizabeth : (Reading), "Mr. Darcy is impatient to see his sister and we are scarcely less eager. I do not think Georgiana Darcy has her rqual for beauty, elegance and accomplishment. I hope to call her hereafter my sister."

Jane :"'Is that not clear enough?"

Elizabeth :"Caroline sees her brother in love with you.... Go to our aunt and uncles in London, Let it be known you are there and I am sure he will come to you." (Time 00:52:46 $\rightarrow 00: 53: 40$ ).

From this scene, the letter from Caroline (Mr. Bingley sister) to Jane imply that Caroline as a noblewoman did not want to have relation to middle class or lower class family than hers. She saw that her brother is in love with Jane. Thus, the coping strategy she chose is leaving Netherfield where Jane lives although they just bought a mansion there. This reflects the culture of people in Regency period where the higher social status people avoid to take bride or groom from lower class. On the contrary, the lower class would do inversely. After all, 
Elizabeth is smart in order to get rid of Jane's anxiety and pain, she told Jane to stay in London for a while to get closer to Mr. Bingley at least vacation.

\section{CONCLUSION AND SUGGESTION}

Based on the research result, the writer conclude that regarding to the issues toward society's view in Regency period reflected in the literary work and movie of Pride and Prejudice written by Jane Austen and movie directed by Joe Wright. The issues about money, marriage, and social status are mirrored along with the anxieties in achieving it and the coping strategies to get rid of unwanted events. In this movie, there are 6 women characters reflect women appearance, mindset, and behavior in Regency period. The number is most of them.

\section{REFERENCES}

Alice Chandler (1996). Sales, Roger. Jane Austen and Representations of Regency England., ANQ: A Quarterly Journal of Short Articles, Notes and Reviews, 9:2, 59-61, DOI: 10.1080/0895769X.1996.10543146

Golemac, A. (2014). Representation of Women in Jane Austen's Pride and Prejudice, Emma, and Persuasion. https://urn.nsk.hr/urn:nbn:hr:142:316788

Hughes, Kristin. 1998. The Writer's Guide to Everyday Life in Regency and Victorian England from 1811-190. Cincinnati: Writer's Digest Books.

Mendez Rodriguez, S. (2010). Re-creating the text: Jane Austen's "Pride and Prejudice" and its film adaptations. In ProQuest Dissertations and Theses.

Morrison, R. (2005). Jane Austen's Pride and prejudice: a sourcebook. In Routledge guides to literature.

Moss, D. (2002). Psychological perspectives: Anxiety disorders: Identification and intervention. Performance Anxiety: Origins and Management, January.

Strossmayera, S. J. J. (2015). Marriage and Women in Jane Austen 's Pride and Prejudice. 2016(4), 59-73.

Wright, Joe, Director. Pride and Prejudice. Performance by Keira Knightley, Studio Canal; Working Title Films, 2005.

Yucht, A. H. (2006). b17. Stress Management Strategies. CSLA Journal, 30(1), 35-36.

\section{British, Jurnal Bahasa dan Sastra Inggris}

